\title{
Novel concentration method for the detection of norovirus and sapovirus from water using minute particles of amorphous calcium phosphate
}

\begin{abstract}
Correspondence
Michiyo Shinohara shinohara.michiyo@ pref.saitama.lg.jp
\end{abstract}

Received 23 September 2010 Accepted 12 February 2011

\author{
Michiyo Shinohara, ${ }^{1,2}$ Kazue Uchida, ${ }^{1}$ Shin-ichi Shimada, ${ }^{1}$ \\ Kyoko Tomioka, ${ }^{1}$ Noriko Suzuki, ${ }^{1}$ Toshitaka Minegishi, ${ }^{1}$ \\ Sachie Kawahashi, ${ }^{1}$ Yuko Yoshikawa ${ }^{2}$ and Norio Ohashi ${ }^{2}$ \\ ${ }^{1}$ Virus Division, Saitama Institute of Public Health, 639-1 Kamiokubo, Sakura-ku, Saitama-shi, \\ Saitama 338-0824, Japan \\ ${ }^{2}$ Laboratory of Microbiology, Department of Food and Nutritional Sciences, Graduate School of \\ Nutritional and Environmental Sciences and Global COE Program, University of Shizuoka, 52-1 \\ Yada, Suruga-ku, Shizuoka-shi, Shizuoka 422-8526, Japan
}

\begin{abstract}
A novel concentration method using minute particles of amorphous calcium phosphate (ACP) was developed for the detection of caliciviruses including norovirus and sapovirus, agents of human gastroenteritis, from water. In seeding experiments with feline calicivirus (FCV), ACP particles were able to adsorb efficiently the viruses in water, and the FCV-concentrated solution was obtained by dissolution of the virus-adsorbing ACP particles with citric acid after centrifugation. By quantitative real-time RT-PCR, the recovery efficiencies from $300 \mathrm{ml}$ ultrapure water seeded with $10^{3}, 10^{4}$ and $>10^{5}$ copies of FCV were 48,68 and $>100 \%$, respectively. A comparative study showed that in the addition of viruses at $<10^{5}$ copies, the recovery efficiency of our method was significantly higher $(P<0.05)$ than that of the similar calcium flocculation-citrate dissolution method. Using our newly developed method, we successfully detected $2.1 \times 10^{4}$ copies $I^{-1}$ of norovirus (each of genogroups I and II) and $5.4 \times 10^{3}$ copies $\mathrm{I}^{-1}$ of sapovirus (genogroups I, II, IV and $\mathrm{V}$ ) from river water. The data suggest that our new viral concentration is a rapid, simple, cost efficient and high virus recovery method, and it can be used for routine monitoring of norovirus and sapovirus in water, especially environmental water.
\end{abstract}

\section{INTRODUCTION}

The family Caliciviridae consists of four genera, Norovirus, Sapovirus, Lagovirus and Vesivirus, which contain norovirus, sapovirus, rabbit haemorrhagic disease virus and feline calicivirus (FCV), respectively. Noroviruses and sapoviruses cause human gastroenteritis. Norovirus is genetically classified into five genogroups (GI to GV). GI, GII and GIV infect humans, whereas GIII and GV infect bovine and murine species, respectively. Most noroviruses that cause human gastroenteritis belong to GI and GII. Sapovirus was first discovered from an outbreak of gastroenteritis in an orphanage in Sapporo, Japan, in 1977 (Chiba et al., 1979). This virus is also divided into five genogroups (GI to GV), of which GI, GII, GIV and GV infect humans, while GIII infects porcine species. Many norovirus outbreaks due to contaminated drinking water have been reported worldwide (Hewitt et al., 2007; Kim

Abbreviations: ACP, amorphous calcium phosphate; CFCD, calcium flocculation-citrate dissolution; FAM, 6-carboxyfluorescein; FCV, feline calicivirus; qRT-PCR, quantitative real-time RT-PCR; TAMRA, 6-carboxytetramethylrhodamine. et al., 2005; Kukkula et al., 1999; Maunula et al., 2005; Nygård et al., 2003; Parshionikar et al., 2003). In Japan, three cases of norovirus infection have recently been reported, probably due to norovirus-contaminated well water (Tokutake et al., 2006). Because only a small number of viruses usually exists in the contaminated water or environmental water, it is hard to detect such causative viruses. Many researchers have developed viral detection methods, especially methods for concentrating a small number of viruses in water (Cliver, 1965; Lucena et al., 1985; Yano et al., 1993). Cliver (1965) have reported the development of a membrane filtration method for concentrating enteroviruses. Other researchers further described modified or improved methods using several membrane filters (Beuret et al., 2002; Fuhrman et al., 2005; Gilgen et al., 1997; Haramoto et al., 2004, 2009; Karim et al., 2009; Katayama et al., 2002; Preston et al., 1988; Shields et al., 1985; Sobsey \& Jones, 1979; Sobsey \& Glass, 1980, 1984). Combination methods with membrane filtration have also been developed: first using concentration by membrane filtration with an electropositively or electronegatively charged filter, followed by organic flocculation, polyethylene 
glycol precipitation or ultrafiltration for reconcentration after elution of the viruses from the virus-bound filter from the first step; and first using concentration by calcium flocculation-citrate dissolution (CFCD) method followed by ultrafiltration for the reconcentration (Katayama et al., 2002; Katzenelson et al., 1976; Lewis \& Metcalf, 1988; Liu et al., 2007). Thus, the membrane filtration method is widely used, but it has some disadvantages, such as (i) clogging of the filter pores during the concentration step; (ii) low recovery of eluted viruses from the membrane-adsorbed viruses in many cases; and (iii) interference in cDNA synthesis and PCR amplification due to the beef extract included in the elute solution. Hence, a new viral concentration method avoiding these problems is still desirable.

Minute particles of amorphous calcium phosphate (ACP) are a precursor of hydroxyapatite, multi-pored and composed of $\mathrm{Ca}_{3}\left(\mathrm{PO}_{4}\right)_{2} \cdot \mathrm{nH}_{2} \mathrm{O}(n=1$ to 2$)$. The surface area of ACP particles is 60 to $100 \mathrm{~m}^{2} \mathrm{~g}^{-1}$, and twofold to tenfold larger than that of hydroxyapatite, suggesting the larger capacity of ACP particles for adsorption of proteins, fatty acids and heavy metals, as well as viruses. Furthermore, ACP particles can be dissolved easily with citric acid; therefore, a high level of recovery of viruses from contaminated water samples would be expected.

In this study, we developed a novel method with ACP particles for concentrating caliciviruses from water samples, and evaluated our method by a comparative study with a similar method (a modified CFCD method) that was originally described by Liu et al. (2007). We further applied the new method for the detection of norovirus and sapovirus from river water.

\section{METHODS}

Virus and cell culture. FCV F9 strain was propagated with the Crandell Reese feline kidney (CRFK) cell line. The CRFK cells were cultured in Eagle's minimum essential medium (Nissui) containing $10 \%$ fetal bovine serum, $0.03 \%$ glutamine and $0.2 \%$ sodium bicarbonate in an incubator at $37{ }^{\circ} \mathrm{C}$ with $5 \% \mathrm{CO}_{2}$. The FCVinfected cells after inoculation of the viruses were maintained in $1 \%$ fetal bovine serum-containing medium. The culture fluid, including cell-free viruses, was harvested after the cytopathic effect was completed, and was stored at $-80{ }^{\circ} \mathrm{C}$ until use for seeding experiments.

Virus concentration. Sterile ultrapure water, river water or artificial seawater (Wako), $300 \mathrm{ml}$ each, was seeded with $1.3 \times 10^{3}$ to $1.3 \times 10^{6}$ copies of FCV F9 strain, which were determined by quantitative realtime RT-PCR (qRT-PCR) as described below. Then, 0.1 or $0.3 \mathrm{~g}$ ACP particles (Sekisui-Kasei) was added to the virus-seeded water samples. Three stirring conditions for optimal adsorption of viruses to ACP particles were examined: stirring vigorously for $24 \mathrm{~h}$ at $4{ }^{\circ} \mathrm{C}$, for $1 \mathrm{~h}$ at room temperature, and for $10 \mathrm{~min}$ at room temperature. After stirring under the respective conditions, the virus-adsorbed particles were collected by centrifugation at $1880 \mathrm{~g}$ for $10 \mathrm{~min}$ and the particle pellet was dissolved completely with $3.3 \mathrm{M}$ citric acid $(1 \mathrm{ml}$ per $0.1 \mathrm{~g}$ ACP particles). The ACP-dissolved solution was used for the determination of viral copy numbers by qRT-PCR as described below, to calculate the recovery efficiency from the seeded water.
Recovery of viruses from water including residual chlorine as a tap water model. Ultrapure water containing 0.1 to 0.5 p.p.m. residual chlorine was prepared with sodium hypochlorite as a tap water model. The chlorinated water sample ( $30 \mathrm{ml}$ of each) was seeded with $3.4 \times 10^{4}$ copies of FCV. In an experiment, ascorbic acid [0.02 g $(30 \mathrm{ml})^{-1}$ ] was added to the virus-seeded water for the reduction of residual chlorine. Then $0.03 \mathrm{~g}$ ACP particles was added to these water samples and stirred for $1 \mathrm{~h}$ at room temperature. The viruses were recovered from the virus-adsorbed particles as described above.

Determination of viral copy numbers by qRT-PCR. RNAs were extracted from $140 \mu \mathrm{l}$ from each of the FCV culture fluids or ACPdissolved solution samples obtained as described above, using a QIAamp viral RNA mini kit (Qiagen) according to the manufacturer's instruction, except $60 \mu$ diethyl-pyrocarbonate-treated water was used for RNA elution from the spin column. The reaction mixture for cDNA synthesis $(30 \mu \mathrm{l})$ contained $15 \mu \mathrm{l}$ extracted RNA, $0.5 \mathrm{mM}$ each dNTP, $5 \mathrm{mM}$ DTT, $2.5 \mu \mathrm{M}$ random hexamers, 30 units RNasin RNase inhibitor (Promega), 300 units SuperScript II RNase H

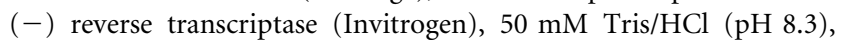
$75 \mathrm{mM} \mathrm{KCl}$ and $3 \mathrm{mM} \mathrm{MgCl}$. The reverse transcription reaction was performed at $42{ }^{\circ} \mathrm{C}$ for $1 \mathrm{~h}$, and the enzyme was then inactivated at $98{ }^{\circ} \mathrm{C}$ for $10 \mathrm{~min}$. The reaction mixture for real-time PCR $(50 \mu \mathrm{l})$ contained $4 \mu \mathrm{l}$ cDNA, $25 \mu \mathrm{l}$ TaqMan universal PCR master mix (Applied Biosystems), $400 \mathrm{nM}$ each primer (F9-3F, 5'-TGCGGTCGATTATTCCAAATG-3', and F9-3R, 5' -CGATCGGAAAA GTAACGAAGGA-3'), and $100 \mathrm{nM}$ fluorogenic probe (F9-3, 5'-FAMTTCGA CCCAATCGCCTCGTGTCAG-TAMRA-3'), as described by Mori et al. (2006). The real-time PCR was performed at $50{ }^{\circ} \mathrm{C}$ for $2 \mathrm{~min}$ to activate, at $95{ }^{\circ} \mathrm{C}$ for $10 \mathrm{~min}$ to inactivate uracil- $\mathrm{N}$ glycosylase and activate Taq polymerase, followed by 40 cycles of amplification with denaturation at $95{ }^{\circ} \mathrm{C}$ for $15 \mathrm{~s}$, annealing and extension at $56{ }^{\circ} \mathrm{C}$ for $1 \mathrm{~min}$ using $\mathrm{ABI}$ Prism 7700 sequence detector or ABI 7900 HT Fast real-time system (Applied Biosystems). The amplification data collected were analysed with Sequence Detector software version 1.6 (Applied Biosystems). For determination of viral copy numbers, a DNA fragment of FCV F9 strain with the positions of 4462-4548 in the genome (GenBank accession number M86379) was synthesized, 10 -fold serially diluted $\left(10^{0}\right.$ to $10^{7}$ copies $\left.\mu 1^{-1}\right)$ and used for standard curve preparation.

Evaluation of our newly developed method. In order to evaluate our new method, a comparative study was performed using the modified CFCD method as originally described by Liu et al. (2007). Briefly, $0.3 \mathrm{ml}$ of each of $1 \mathrm{M} \mathrm{CaCl}_{2}$ and $1 \mathrm{M} \mathrm{Na}_{2} \mathrm{HPO}_{4}$ was added into a $300 \mathrm{ml}$ ultrapure-water sample seeded with $10^{4}$ to $10^{6}$ copies of FCV, and stirred for $5 \mathrm{~min}$ or $1 \mathrm{~h}$ to form flocculates. The viruscontaining flocculates were collected by centrifugation at $1880 \mathrm{~g}$ for $30 \mathrm{~min}$. The flocculate pellets were dissolved with $1.2 \mathrm{ml} 0.3 \mathrm{M}$ citric acid buffer ( $\mathrm{pH} 3.5)$ and the viral copy numbers in the dissolved-flocculate solution were determined by qRT-PCR as described above.

Detection of noroviruses and sapoviruses from river water. Six samples ( $\mathrm{pH} 7.4$, turbidity 6.1) were collected at the same point of Tonegawa river located in a northern part of Saitama prefecture, Japan, on 13 March 2008. Of these six river-water samples, three (300 ml of each) were seeded with $1.3 \times 10^{4}$ copies of FCV to confirm the virus recovery efficiency. Then, $0.3 \mathrm{~g}$ ACP particles was added into $300 \mathrm{ml}$ of each of the six river-water samples and stirred for $1 \mathrm{~h}$ at room temperature, and the viruses were recovered from virus-adsorbed particles as described above. The qRT-PCR was conducted for detection of norovirus RNA (GI and GII) and sapovirus RNA (GI, GII, GIV and GV) as described by Kageyama et al. (2003) and Oka et al. (2006), respectively, as well as FCV RNA as described above. 
Statistical analysis. Statistical differences were determined by twosided Student's $t$-test. A difference with $P<0.05$ was considered significant.

\section{RESULTS}

\section{Recovery efficiencies under various virus- adsorbing conditions}

Seeding experiments with $1.3 \times 10^{6}$ copies of FCV in $300 \mathrm{ml}$ ultrapure-water samples were performed for examination of the recovery efficiencies under various virus-adsorbing conditions. As shown in Table 1, the recovery efficiencies with $0.3 \mathrm{~g} \mathrm{ACP}$ particles were significantly higher than those with $0.1 \mathrm{~g} \mathrm{ACP}$ particles kept under the virus-adsorbing conditions for $24 \mathrm{~h}$ at $4{ }^{\circ} \mathrm{C}$ ( 151 and $23 \%$ for 0.3 and $0.1 \mathrm{~g}$ of ACP particles, respectively, $P=0.001)$, and for $1 \mathrm{~h}$ at room temperature (105 and $34 \%$ for 0.3 and $0.1 \mathrm{~g}$ of ACP particles, respectively, $P=0.001$ ). The results showed that the addition of $0.3 \mathrm{~g}$ ACP particles in $300 \mathrm{ml}$ seems to be suitable for the viral adsorption in our method. Additionally, the recovery when using the longer stirring time for the viral adsorption with $0.3 \mathrm{~g}$ ACP particles significantly increased $(P=0.009$, Table 1$)$. However, the adsorption of viruses to ACP particles for $24 \mathrm{~h}$ seems to be impractical since it takes too much time to detect the viruses for routine monitoring of contaminated water. Therefore, for further examinations, we carried out virus adsorption for $1 \mathrm{~h}$ or $10 \mathrm{~min}$, but not $24 \mathrm{~h}$, after the addition of ACP particles.

\section{Sensitivity in our newly developed method}

The sensitivity was examined using $10^{3}$ copies of FCV (as the lowest copy number) or more in $300 \mathrm{ml}$ ultrapurewater samples, and $0.3 \mathrm{~g}$ ACP particles for viral adsorption. The recovery efficiencies from water samples seeded with $1.3 \times 10^{3}, 1.3 \times 10^{4}$ and $1.3 \times 10^{5}$ copies of FCV were 48,62 and $132 \%$, respectively, by stirring for $1 \mathrm{~h}$, and 29,26 and $80 \%$, respectively, for $10 \mathrm{~min}$ (Table 2). Because this new method could detect $10^{3}$ copies of viruses even with stirring for $10 \mathrm{~min}$, it appears to be a high virus recovery method. The recoveries after stirring for $1 \mathrm{~h}$ were significantly increased when compared to those after stirring for $10 \mathrm{~min}(P=0.02)$, suggesting that viral adsorption for $1 \mathrm{~h}$ is more suitable than adsorption for $10 \mathrm{~min}$.

We next tested the recovery of viruses from river-water samples $(300 \mathrm{ml})$ seeded with $1.3 \times 10^{4}$ copies of FCV. As shown in Table 2, the recovery from river-water samples $(59 \%)$ was similar to that from ultrapure-water samples $(62 \%)$, suggesting that our method is applicable for viral monitoring in river water. We further examined the recovery of viruses from artificial-seawater samples. In this experiment, $5 \mathrm{ml}$ citric acid, but not $3 \mathrm{ml}$ in the cases of pure water and river-water samples, was required for the complete dissolution of virus-adsorbed ACP particles. The recovery from artificial seawater samples seeded with $10^{4}$ and $10^{5}$ copies of FCV was decreased (15 and $41 \%$, respectively) when compared with recovery from the seeded water (62 and $132 \%$, respectively), but the lower copy numbers $\left(10^{4}\right)$ in the artificial seawater were still detectable (Table 2). In another experiment, we examined the recovery from ultrapure water containing sodium hypochlorite, as a model of tap water. As shown in Table 3, the recovery of viruses was remarkably interfered with by $\geqslant 0.2$ p.p.m. chlorine. However, when the sodium hypochlorite-containing water sample was dechlorinated with ascorbic acid, the decreased viral recovery was reversed, suggesting that our method using the addition of ascorbic acid may be applicable for the detection of viruses in tap water.

\section{Evaluation of our newly developed method}

To evaluate our new method with ACP particles, a comparative study was performed using the modified CFCD method. As mentioned above, the stirring for $1 \mathrm{~h}$ is a suitable condition for the viral adsorption in our method, but Liu et al. (2007) have recommended stirring for $5 \mathrm{~min}$ in the CFCD method. As shown in Table 4, in seeding experiments with a larger number of viruses $\left(10^{6}\right.$ copies $)$, the recovery efficiencies in our method (stirring for $1 \mathrm{~h}$ )

Table 1. Recovery of FCV from ultrapure-water samples seeded with $10^{6}$ copies of the viruses by concentration with ACP particles

\begin{tabular}{|lccccccc|}
\hline $\begin{array}{l}\text { No. of virus } \\
\text { seeded } \\
\text { (copies) }\end{array}$ & $\begin{array}{c}\text { No. of } \\
\text { samples } \\
\text { tested }\end{array}$ & $\begin{array}{c}\text { Water } \\
\text { volume } \\
(\mathbf{m l})\end{array}$ & $\begin{array}{c}\text { Amount of } \\
\text { ACP particles } \\
\text { added }(\mathbf{g})\end{array}$ & $\begin{array}{c}\text { Stirring time } \\
\text { and temp. }\end{array}$ & $\begin{array}{c}\text { Mean no. of } \\
\text { viruses recovered } \\
\text { (copies) }\end{array}$ & $\begin{array}{c}\text { Range of } \\
\text { recovery } \\
\text { (copies) }\end{array}$ & $\begin{array}{c}\text { Mean } \\
\text { recovery } \\
(\%)\end{array}$ \\
\hline $1.3 \times 10^{6}$ & 3 & 300 & 0.1 & $24 \mathrm{~h}, 4{ }^{\circ} \mathrm{C}$ & $3.0 \times 10^{5}$ & $2.4 \times 10^{5}-4.3 \times 10^{5}$ \\
$1.3 \times 10^{6}$ & 6 & 300 & 0.1 & $1 \mathrm{~h}$, room temp. & $4.4 \times 10^{5}$ & $3.1 \times 10^{4}-1.3 \times 10^{6}$ \\
$1.3 \times 10^{6}$ & 3 & 300 & 0.3 & $24 \mathrm{~h}, 4{ }^{\circ} \mathrm{C}$ & $2.0 \times 10^{6}$ & $1.6 \times 10^{6}-2.3 \times 10^{6}$ \\
$1.3 \times 10^{6}$ & 6 & 300 & 0.3 & $1 \mathrm{~h}$, room temp. & $1.5 \times 10^{6}$ & $1.1 \times 10^{6}-2.4 \times 10^{6}$ \\
$1.3 \times 10^{6}$ & 8 & 300 & 0.3 & 10 min, room temp. & $1.2 \times 10^{6}$ & $1.7 \times 10^{5}-2.0 \times 10^{6}$ \\
\end{tabular}

${ }^{\star}$ For samples stirred for $24 \mathrm{~h}$ at $4{ }^{\circ} \mathrm{C}$, the virus recovery with $0.3 \mathrm{~g} \mathrm{ACP}$ particles was significantly higher than that with $0.1 \mathrm{~g}$ particles $(P=0.001)$. The recovery was significantly higher for samples stirred for a longer time $(P=0.009)$.

$\dagger$ For samples stirred for $1 \mathrm{~h}$ at room temperature, the virus recovery with $0.3 \mathrm{~g}$ ACP particles was significantly higher than that with $0.1 \mathrm{~g}$ particles $(P=0.001)$. 
Table 2. Recovery of FCV from ultrapure-water, river-water and artificial-seawater samples seeded with different numbers of viruses by adsorption to ACP particles for $10 \mathrm{~min}$ or for $1 \mathrm{~h}$

\begin{tabular}{|c|c|c|c|c|c|c|c|}
\hline $\begin{array}{l}\text { No. of viruses } \\
\text { seeded } \\
\text { (copies) }\end{array}$ & $\begin{array}{l}\text { No. of } \\
\text { samples } \\
\text { tested }\end{array}$ & $\begin{array}{c}\text { Water } \\
\text { volume } \\
(\mathrm{ml})\end{array}$ & $\begin{array}{l}\text { Amount of } \\
\text { ACP particles } \\
\text { added (g) }\end{array}$ & $\begin{array}{l}\text { Stirring time } \\
\text { and temp. }\end{array}$ & $\begin{array}{c}\text { Mean no. of } \\
\text { viruses recovered } \\
\text { (copies) }\end{array}$ & $\begin{array}{l}\text { Range of } \\
\text { recovery } \\
\text { (copies) }\end{array}$ & $\begin{array}{c}\text { Mean } \\
\text { recovery } \\
(\%)\end{array}$ \\
\hline $1.3 \times 10^{4}$ & 3 & 300 & 0.3 & $10 \mathrm{~min}$, room temp. & $3.4 \times 10^{3}$ & $6.8 \times 10^{2}-4.8 \times 10^{3}$ & 26 \\
\hline $1.3 \times 10^{3}$ & 4 & 300 & 0.3 & $10 \mathrm{~min}$, room temp. & $3.7 \times 10^{2}$ & $3.2 \times 10^{2}-4.3 \times 10^{2}$ & 29 \\
\hline $1.3 \times 10^{5}$ & 7 & 300 & 0.3 & $1 \mathrm{~h}$, room temp. & $1.7 \times 10^{5}$ & $1.3 \times 10^{5}-2.8 \times 10^{5}$ & $132^{*}$ \\
\hline $1.3 \times 10^{3}$ & 7 & 300 & 0.3 & $1 \mathrm{~h}$, room temp. & $6.3 \times 10^{2}$ & $2.9 \times 10^{2}-1.1 \times 10^{3}$ & $48^{*}$ \\
\hline $1.3 \times 10^{4}$ & 4 & 300 & 0.3 & $1 \mathrm{~h}$, room temp. & $7.6 \times 10^{3}$ & $4.3 \times 10^{3}-1.1 \times 10^{4}$ & $59 \dagger$ \\
\hline $2.8 \times 10^{5}$ & 4 & 300 & 0.3 & $1 \mathrm{~h}$, room temp. & $1.1 \times 10^{5}$ & $8.0 \times 10^{4}-1.8 \times 10^{5}$ & $41 \ddagger$ \\
\hline $2.8 \times 10^{4}$ & 4 & 300 & 0.3 & $1 \mathrm{~h}$, room temp. & $4.3 \times 10^{3}$ & $3.1 \times 10^{2}-8.9 \times 10^{3}$ & $15 \ddagger$ \\
\hline
\end{tabular}

${ }^{\star}$ Recoveries from samples stirred for $1 \mathrm{~h}$ were significantly higher $(P=0.02)$ when compared to those stirred for $10 \mathrm{~min}$.

$\dagger$ From river-water samples seeded with FCV.

$\ddagger$ From artificial-seawater samples seeded with FCV.

were almost same as for the modified CFCD method (stirring for $5 \mathrm{~min}$ ). However, in the addition of a lower number of viruses ( $<10^{5}$ copies), the recovery efficiencies by our method (stirring for $1 \mathrm{~h}$ ) were significantly higher than those by the modified CFCD method (132 and $43 \%$ in our method and CFCD, respectively, for the addition of $10^{5}$ copies, $P=0.017 ; 62$ and $16 \%$ in our method and CFCD, respectively, for the addition of $10^{4}$ copies, $P=0.013$ ). We extended the stirring to $1 \mathrm{~h}$ in the modified CFCD method, but the recovery of viruses did not seem to be improved (Table 4).

\section{Detection of norovirus and sapovirus from river- water samples using the ACP-concentration method}

Six water samples were collected at the same positions in the Tonegawa river for detection of norovirus and

Table 3. Virus recovery from chlorinated water with or without ascorbic acid

\begin{tabular}{|lcc|}
\hline $\begin{array}{l}\text { Concentration } \\
\text { of chlorine } \\
\text { (p.p.m.) }\end{array}$ & \multicolumn{2}{c|}{$\begin{array}{c}\text { Percentage recovery from } \\
\text { chlorinated water }\end{array}$} \\
\cline { 2 - 3 } & $\begin{array}{c}\text { Without ascorbic } \\
\text { acid }^{*}\end{array}$ & $\begin{array}{c}\text { With ascorbic } \\
\text { acid }^{*}\end{array}$ \\
\hline 0.1 & $125(81-169)$ & $100(67-150)$ \\
0.2 & $1.1(0.1-3.5)$ & $146(120-168)$ \\
0.3 & $0.7(0-1.9)$ & $93(49-117)$ \\
0.4 & 0 & $90(66-128)$ \\
0.5 & 0 & $87(73-95)$ \\
\hline
\end{tabular}

${ }^{*}$ Numbers in parentheses represent the recovery range as a percentage. sapovirus. As shown in Table 5, we successfully detected $1.2 \times 10^{4}$ to $3.7 \times 10^{4}$ copies $1^{-1}$ (mean of $2.1 \times 10^{4}$ copies $1^{-1}$ ) of norovirus GI from five river samples, but not from one sample, and $6.7 \times 10^{3}$ to $3.6 \times 10^{4}$ copies $1^{-1}$ (mean of $2.1 \times 10^{4} 1^{-1}$ ) of norovirus GII from all six river samples. Additionally we could detect $5.4 \times 10^{2}$ to $1.0 \times 10^{4}$ copies $1^{-1}$ (mean of $5.4 \times 10^{3} 1^{-1}$ ) of sapovirus GI, GII, GIV and $\mathrm{GV}$. Of the six river-water samples, three samples $(300 \mathrm{ml}$ of each) were seeded with $1.3 \times 10^{4}$ copies of FCV to confirm the recovery efficiency (samples 4 to 6 in Table 5). The mean recovery of FCV was $67 \%$, which was similar to $59 \%$ obtained in Table 2.

\section{DISCUSSION}

An important procedure for the detection of enteric viruses, especially the causative agents of human gastroenteritis, in drinking water or environmental water is the efficient concentration of such viruses from water samples. This study describes a new method using ACP particles for concentrating FCVs, noroviruses and sapoviruses from water samples. The data showed that the recovery from $300 \mathrm{ml}$ ultrapure-water samples seeded with $10^{5}$ copies of FCV or more seemed to be accomplished completely $(>100 \%)$ by the adsorption of viruses to ACP particles by stirring for $1 \mathrm{~h}$ at room temperature. Additionally, at least up to $10^{3}$ copies of viruses in $300 \mathrm{ml}$ water samples were detectable in our method. The recovery from river water seeded with $10^{4}$ copies of FCV (approx. $60 \%$ ) was almost equivalent to that from ultrapure water $(62 \%)$. However, the recovery from artificial seawater seeded with $10^{5}$ copies of FCV or less was decreased $(<41 \%)$ when compared to that from the seeded pure water $(<132 \%)$. It is known that, in the binding of proteins to hydroxyapatite, the proteins compete with cations present in the solution. Therefore, the same competitive event between viruses and 
Table 4. Comparison of virus recovery for the ACP method and the modified CFCD method

\begin{tabular}{|lcccc|}
\hline $\begin{array}{l}\text { No. of virus } \\
\text { seeded (copies) }\end{array}$ & $\begin{array}{c}\text { Mean recovery (\%) } \\
\text { by ACP method }\end{array}$ & & \multicolumn{2}{c|}{$\begin{array}{c}\text { Mean recovery (\%) by } \\
\text { modified CFCD method }\end{array}$} \\
\cline { 2 - 3 } \cline { 4 - 5 } & Stirring for $\mathbf{1 ~ h}$ & & Stirring for $\mathbf{5}$ min & Stirring for $\mathbf{1} \mathbf{~ h}$ \\
\hline $10^{6}$ & $105(85-123)$ & & $121(75-169)$ & NT \\
$10^{5}$ & $132(100-215)$ & & $43(33-53)$ & $28(15-39)$ \\
$10^{4}$ & $62(25-108)$ & $16(9-31)$ & $30(15-38)$ \\
\hline
\end{tabular}

NT, Not tested.

${ }^{\star}$ Numbers in parentheses represent the recovery range as a percentage.

cations, such as magnesium ions, present in artificial seawater might occur during the binding to ACP particles. In the present study, occasionally the virus recovery became more than $100 \%$. Other researchers have also reported $>150 \%$ recovery of viruses (Haramoto et al., 2009; Karim et al., 2009). The reason for this is not clear. One possibility is that the virus recovery of more than $100 \%$ may be generated by the aggregation of viruses in stock solution.

For the comparative study, we used the modified CFCD method as originally described by Liu et al. (2007), because its technique was similar to our method, i.e. viruscontaining flocculates were formed with $\mathrm{CaCl}_{2}$ and $\mathrm{NaHPO}_{4}$, and viruses were recovered by dissolution of the flocculates with citric acid. As shown in Table 4, in the seeding experiment with $10^{6}$ copies of FCV, the viral recovery by the modified $\mathrm{CFCD}$ method was complete $(>100 \%)$ the same as for our new method, but it was still fourfold less recovery efficient than our method in the lower-virus-number seeding $\left(10^{4}\right.$ to $10^{5}$ copies $)$. Our ACPparticle concentration method was further compared, for recovery efficiency, with previously published methods using several membrane filters. Haramoto et al. (2009)

Table 5. Detection of norovirus and sapovirus from river-water samples using the ACP-concentration method developed in this study

\begin{tabular}{|lcccc|}
\hline $\begin{array}{l}\text { River } \\
\text { sample }\end{array}$ & $\begin{array}{c}\text { Norovirus GI } \\
\left.\text { copies 1 }^{-\mathbf{1}}\right)\end{array}$ & $\begin{array}{c}\text { Norovirus GII } \\
\left(\text { copies 1 }^{-\mathbf{1}}\right)\end{array}$ & $\begin{array}{c}\text { Sapovirus* } \\
\left.\text { copies 1 }^{-\mathbf{1}}\right)\end{array}$ & $\begin{array}{c}\text { Mean of } \\
\text { recovery of } \\
\text { FCV }(\%) \dagger\end{array}$ \\
\hline 1 & 0 & $3.4 \times 10^{4}$ & $1.7 \times 10^{3}$ & $\mathrm{NT}$ \\
2 & $1.2 \times 10^{4}$ & $6.7 \times 10^{3}$ & $2.7 \times 10^{3}$ & $\mathrm{NT}$ \\
3 & $3.7 \times 10^{4}$ & $8.2 \times 10^{3}$ & $5.4 \times 10^{2}$ & $\mathrm{NT}$ \\
4 & $2.6 \times 10^{4}$ & $3.6 \times 10^{4}$ & $9.2 \times 10^{3}$ & 73 \\
5 & $1.8 \times 10^{4}$ & $8.8 \times 10^{3}$ & $1.0 \times 10^{4}$ & 48 \\
6 & $3.2 \times 10^{4}$ & $3.0 \times 10^{4}$ & $7.9 \times 10^{3}$ & 80 \\
Mean & $2.1 \times 10^{4}$ & $2.1 \times 10^{4}$ & $5.4 \times 10^{3}$ & 67 \\
\hline
\end{tabular}

NT, Not tested.

${ }^{*}$ Genogroups I, II, III and V.

$\dagger$ From river-water samples seeded with $1.3 \times 10^{4}$ copies of FCV (samples 4 to 6). have reported that, in an Mg-method with an electronegatively charged filter, the mean recovery from $500 \mathrm{ml}$ ultrapure water seeded with $2.65 \times 10^{5}-9.50 \times 10^{5}$ copies of noroviruses was $186 \%$ (range $172-200 \%$ ), but it was only $15 \%$ (range $11-18 \%$ ) when $250 \mathrm{ml}$ river water was seeded with $6.75 \times 10^{4}-1.38 \times 10^{5}$ copies. They have suggested that the low recovery from river water in their method was likely due to substances in river water partially blocking the filter pores and inhibiting the effective elution of viruses from the filter. They have further described that the recoveries were $71 \%$ (range $47-94 \%$ ) when river water was seeded with $9.00 \times 10^{5}-2.33 \times 10^{6}$ copies of polioviruses. Fuhrman et al. (2005) have shown that using negatively charged filters, the recoveries in seeding experiments with $>10^{4}$ and $<10^{4}$ copies of polioviruses were $51.2 \% \pm 1.9 \%$ and $16.7 \% \pm 0.8 \%$, respectively, in freshwater, and $22.6 \% \pm 2.8 \%$ and $12.3 \% \pm 1.3 \%$, respectively, in seawater samples. For our method, the recovery was complete from ultrapure-water samples seeded with $>10^{5}$ copies $(>100 \%)$ and it was still $48 \%$ (range $23-85 \%$ ) for the lowest level of virus addition $\left(10^{3}\right.$ copies). Because we do not use filter concentration, the viral recovery appears not to be interfered with by substances in river water. In seawater, the recovery efficiency for our method (15\% from artificial seawater with $10^{4}$ copies added) appeared to be similar to those for membrane filtration methods used by Fuhrman et al. (2005). Taken together, in the detection of a lower number of viruses $\left(<10^{4}\right.$ copies), our method seems to be more recovery-efficient than the other methods with membrane filters as well as the modified CFCD method as described above (except in the case of seawater). Additionally, our method suggests that, although the solution after the dissolution of virus-adsorbed ACP particles with citric acid becomes acidic, the detection of FCV, norovirus and sapovirus seems not to be influenced by such low $\mathrm{pH}$. Because norovirus and sapovirus, which cause gastroenteritis, need to go through a gastric environment with low $\mathrm{pH}$ to reach the intestine/colon for establishment of their infection, they are likely to be stable under acidic conditions as described by Cannon et al. (2006).

In published reports with differently charged filters, Haramoto et al. (2009) have described that the recovery efficiencies of norovirus and poliovirus type 1 by the 
Mg-method and the Al-method with electronegatively charged filters were similar to each other, but there was a difference between the recoveries of these two different viruses by the 1MDS-method with an electropositively charged filter. Karim et al. (2009) have reported that, in viral concentration with an electropositively charged NanoCeram filter for a large amount of water $(100 \mathrm{l})$, the recoveries of coxsackievirus B5 and echovirus 7 were lower than that of poliovirus. These observations led us to speculate that viral recoveries might be influenced by electric charge differences on the surfaces of respective viruses. Accordingly, we may need to consider such viral surface charges as well as viral stabilities under acidic conditions for individual viruses in the application of our method to detect other viruses in future studies. In Japan, it is well known that gastroenteritis caused by noroviruses or sapoviruses is quite prevalent in the winter season. Probably, it is a seasonal association with the high level of virus contamination in the river, especially in early spring through winter. Indeed, other researchers have also reported the high level of contamination in the river in the winter season (Yamamoto et al., 2005). Therefore, the potential sources of faecal contamination in the river from the patients should be considered for public health significance.

In conclusion, our novel virus concentration method consists of the adsorption of viruses to ACP particles in water samples, the collection of virus-adsorbed particles by centrifugation, and the dissolution of the particles with citric acid. Our method does not require the adjustment of $\mathrm{pH}$, the addition of $\mathrm{MgCl}_{2}$, or the membrane filtration that were usually necessary in previous methods. Our viral detection using the newly developed ACP-particle concentration is a rapid, simple, inexpensive and sensitive method, and it will be applicable for routine monitoring of viruses such as noroviruses and sapoviruses (causative agents of human gastroenteritis) in water, especially environmental water.

\section{ACKNOWLEDGEMENTS}

We thank Dr Motonobu Hara at the School of Veterinary Medicine, Azabu University, Japan, for providing FCV and the CRFK cell line.

\section{REFERENCES}

Beuret, C., Kohler, D., Baumgartner, A. \& Lüthi, T. M. (2002). Norwalk-like virus sequences in mineral waters: one-year monitoring of three brands. Appl Environ Microbiol 68, 1925-1931.

Cannon, J. L., Papafragkou, E., Park, G. W., Osborne, J., Jaykus, L.-A. \& Vinjé, J. (2006). Surrogates for the study of norovirus stability and inactivation in the environment: a comparison of murine norovirus and feline calicivirus. J Food Prot 69, 2761-2765.

Chiba, S., Sakuma, Y., Kogasaka, R., Akihara, M., Horino, K., Nakao, T. \& Fukui, S. (1979). An outbreak of gastroenteritis associated with calicivirus in an infant home. J Med Virol 4, 249-254.

Cliver, D. O. (1965). Factors in the membrane filtration of enteroviruses. Appl Microbiol 13, 417-431.
Fuhrman, J. A., Liang, X. \& Noble, R. T. (2005). Rapid detection of enteroviruses in small volumes of natural waters by real-time quantitative reverse transcriptase PCR. Appl Environ Microbiol 71, 4523-4530.

Gilgen, M., Germann, D., Lüthy, J. \& Hübner, P. (1997). Three-step isolation method for sensitive detection of enterovirus, rotavirus, hepatitis A virus, and small round structured viruses in water samples. Int J Food Microbiol 37, 189-199.

Haramoto, E., Katayama, H. \& Ohgaki, S. (2004). Detection of noroviruses in tap water in Japan by means of a new method for concentrating enteric viruses in large volumes of freshwater. Appl Environ Microbiol 70, 2154-2160.

Haramoto, E., Katayama, H., Utagawa, E. \& Ohgaki, S. (2009). Recovery of human norovirus from water by virus concentration methods. J Virol Methods 160, 206-209.

Hewitt, J., Bell, D., Simmons, G. C., Rivera-Aban, M., Wolf, S. \& Greening, G. E. (2007). Gastroenteritis outbreak caused by waterborne norovirus at a New Zealand ski resort. Appl Environ Microbiol 73, 7853-7857.

Kageyama, T., Kojima, S., Shinohara, M., Uchida, K., Fukushi, S., Hoshino, F. B., Takeda, N. \& Katayama, K. (2003). Broadly reactive and highly sensitive assay for Norwalk-like viruses based on real-time quantitative reverse transcription-PCR. J Clin Microbiol 41, 15481557.

Karim, M. R., Rhodes, E. R., Brinkman, N., Wymer, L. \& Fout, G. S. (2009). New electropositive filter for concentrating enteroviruses and noroviruses from large volumes of water. Appl Environ Microbiol 75, 2393-2399.

Katayama, H., Shimasaki, A. \& Ohgaki, S. (2002). Development of a virus concentration method and its application to detection of enterovirus and norwalk virus from coastal seawater. Appl Environ Microbiol 68, 1033-1039.

Katzenelson, E., Fattal, B. \& Hostovesky, T. (1976). Organic flocculation: an efficient second-step concentration method for the detection of viruses in tap water. Appl Environ Microbiol 32, 638-639.

Kim, S.-H., Cheon, D.-S., Kim, J.-H., Lee, D.-H., Jheong, W. H., Heo, Y.-J., Chung, H.-M., Jee, Y. \& Lee, J.-S. (2005). Outbreaks of gastroenteritis that occurred during school excursions in Korea were associated with several waterborne strains of norovirus. J Clin Microbiol 43, 4836-4839.

Kukkula, M., Maunula, L., Silvennoinen, E. \& Von Bonsdorff, C.-H. (1999). Outbreak of viral gastroenteritis due to drinking water contaminated by Norwalk-like viruses. J Infect Dis 180, 17711776.

Lewis, G. D. \& Metcalf, T. G. (1988). Polyethylene glycol precipitation for recovery of pathogenic viruses, including hepatitis A virus and human rotavirus, from oyster, water, and sediment samples. Appl Environ Microbiol 54, 1983-1988.

Liu, J., Wu, Q. \& Kou, X. (2007). Development of a virus concentration method and its application for the detection of noroviruses in drinking water in China. J Microbiol 45, 48-52.

Lucena, F., Bosch, A., Jofre, J. \& Schwartzbrod, L. (1985). Identification of viruses isolated from sewage, riverwater and coastal seawater in Barcelona. Water Res 19, 1237-1239.

Maunula, L., Miettinen, I. T. \& Von Bonsdorff, C.-H. (2005). Norovirus outbreaks from drinking water. Emerg Infect Dis 11, 1716-1721.

Mori, K., Hayashi, Y., Noguchi, Y., Kai, A., Ohe, K., Sakai, S., Hara, M. \& Morozumi, S. (2006). [Effects of handwashing on feline calicivirus removal as norovirus surrogate]. Kansenshogaku Zasshi 80, 496-500 (in Japanese). 
Nygård, K., Torvén, M., Ancker, C., Knauth, S. B., Hedlund, K.-O., Giesecke, J., Andersson, Y. \& Svensson, L. (2003). Emerging genotype (GGIIb) of norovirus in drinking water, Sweden. Emerg Infect Dis 9, 1548-1552.

Oka, T., Katayama, K., Hansman, G. S., Kageyama, T., Ogawa, S., Wu, F.-T., White, P. A. \& Takeda, N. (2006). Detection of human sapovirus by real-time reverse transcription-polymerase chain reaction. J Med Virol 78, 1347-1353.

Parshionikar, S. U., Willian-True, S., Fout, G. S., Robbins, D. E., Seys, S. A., Cassady, J. D. \& Harris, R. (2003). Waterborne outbreak of gastroenteritis associated with a norovirus. Appl Environ Microbiol 69, 5263-5268.

Preston, D. R., Vasudevan, T. V., Bitton, G., Farrah, S. R. \& Morel, J.-L. (1988). Novel approach for modifying microporous filters for virus concentration from water. Appl Environ Microbiol 54, 13251329.

Shields, P. A., Berenfeld, S. A. \& Farrah, S. R. (1985). Modified membrane-filter procedure for concentration of enteroviruses from tap water. Appl Environ Microbiol 49, 453-455.
Sobsey, M. D. \& Glass, J. S. (1980). Poliovirus concentration from tap water with electropositive adsorbent filters. Appl Environ Microbiol 40, 201-210.

Sobsey, M. D. \& Glass, J. S. (1984). Influence of water quality on enteric virus concentration by microporous filter methods. Appl Environ Microbiol 47, 956-960.

Sobsey, M. D. \& Jones, B. L. (1979). Concentration of poliovirus from tap water using positively charged microporous filters. Appl Environ Microbiol 37, 588-595.

Tokutake, Y., Kobayashi, M., Akiyama, M., Aiki, C. \& Nishio, O. (2006). [Food borne outbreak caused by the well water contaminated norovirus]. Kansenshogaku Zasshi 80, 238-242 (in Japanese).

Yamamoto, T., Shimazu, T., Endo, Y., Shiraishi, H. \& Kageyama, T. (2005). Quantitative detection of norovirus in water samples collected from rivers flowing into oyster farms in Miyagi Prefecture, Japan. J Jap Soc Wat Environ 28, 515-521.

Yano, K., Yoshida, Y., Shinkai, T. \& Kaneko, M. (1993). A practical method for the concentration of viruses from water using fibriform cellulose and organic coagulant. Water Sci Technol 27, 295-298. 